\title{
FINANCIAL LITERACY OF MICRO, SMALL, AND MEDIUM ENTERPRISES OF CONSUMPTION SECTOR IN PROBOLINGGO CITY
}

\author{
Elok Sri Utami ${ }^{1 *}$, Mega Rizky Aprilia ${ }^{2}$, Ihrom Caesar Ananta Putra ${ }^{3}$ \\ ${ }^{1,2,3}$ Faculty of Economics and Business, University of Jember \\ Email: 1elok_utami@yahoo.co.id, ${ }^{2}$ mgrzkyapr@gmail.com, ${ }^{3}$ ihromcaesar13@gmail.com \\ ${ }^{*}$ Corresponding author
}

\begin{abstract}
Financial literacy among the owners of Micro, Small, and Medium Enterprises (MSMEs) had been an issue attracting scholar as it determines the success of the business. Financial literacy was commonly related to financial behavior and performance of the business. This study aimed to analyize the financial literacy, use of technology, financial behavior, and performance of MSMEs in the Consumption Sector in Probolinggo City. It examined a total of $51 \mathrm{MSMEs}$ that had been in operation for three years. Data were obtained by distributing questionnaires consisting of questions in the form of dichotomus and Likert scale to identify the level of financial literacy, use of technology, and financial behavior among MSME owners. The results indicated that the financial literacy among the owners is at medium level. The owners had little use of technology in supporting their business activities. However, they had shown responsibility of financial behavior that can improve the performance of the business they manage.
\end{abstract}

Keywords: Financial literacy of MSMEs, behavior, technology, performance.

\section{Introduction}

According to Statistics Center Bureau, MSME is a business unit considered from the labor quantity divided into micro scale business, small scale business, and medium scale business. MSME contributes to the Gross Domestic Product (GDP) of Indonesia which is gradually to increase since 2012-2016. MSME absorbs 97.22\% labor from previously 96.99\% (Kemenperin, 2016). In the case of Probolinggo City, in 2018, there were 5,033 MSMEs registered in the Agency of Cooperation Business, Micro Business, Trade and Industry (DKUPP) of Probolinggo City.

In Probolinggo, the MSMEs are divided into four sectors, namely trade, consumption, non-consumption, and service. The consumption sector of MSME is divided further into several subsectors such as culinary, fashion, and handcraft which are considered to contribute greatly for Probolinggo city since they support the business development and tourism potential of Probolinggo city through their products. The Mayor of Probolinggo initiates a program which is to establish 500 business units every year.

MSMEs have been known to play an important role in the economy, in particular for alleviating the poverty and unemployment problems. However, MSMEs have been facing several and never ended problems, such as human resource, ownership, funding, marketing, and others related to the business development that the MSME could not perform optimally (Abor \& Qurtey, 2010). Limited amount of capital, low quality human resource, and the lack of technology use to support the business have made MSMEs in a high risk of being fail.

Several potential solutions for the MSMEs problems include increasing the financial literacy of the MSME business-people. Financial literacy is related to the knowledge and understanding required to create a better financial management. The managers or owners of MSMEs are demanded to have adequate financial literacy in order to properly manage financial matters of the business.

One way of assessing the understanding on financial literacy is by observing a person's way in processing financial information and making a decision based on the financial knowledge (Lusardi, Mitchell, \& Curto, 2010). Financial literacy helps the MSMEs' owners to avoid financial management error (Krishna, Rofaida, \& Sari, 2010). The Indonesia Financial Service Authority explains that the increasing financial literacy will enable the society to determine the suitable financial product and/or service needed and improve the financial condition that the MSMEs' owners need bigger responsibility in increasing their financial literacy (Fatoki, 2014). Kasendah and Wijayangka (2019) report that financial literacy had a positive and significant effect on MSME performance. Aribawa (2016) shows that financial literacy had a significant effect on MSME performance and continuity. In addition to financial literacy, MSMEs need technology for the operation, production, marketing activities, and other needs (Ardiansari, Cahyaningdyah, \& Slamet, 
2016; Hussain, Salia, \& Karim, 2018; Mabula \& Ping, 2018).

Technology is a tool to boost the productivity of a business. Technology mastery is required to enable the MSME to compete in the era of industry 4.0. The global competition and an urge to stimulate the business growth are the reasons why the MSME owner must utilize the information and communication technology (Niebel, 2018; Yunis, El-Kassar, \& Tarhini, 2017). Some possible technologies to use in the MSME include information, communication and industrial technology.

One of the Information Communication Technology (ICT) products currently being used in the business world is the financial technology (fintech). There are many examples of fintech. In the payment service we cotice OVO or GoPay. In the investment service includes IpotFund, or in the funding service such as debt financing, crowdfunding and peer-to-peer and marketplace service such as Shopee and Lazada. The benefits of using ICT for MSME may include the effectiveness and efficiency in operating business, increase the income or profit and create an innovative product which can compete in the global market (Okundaye, Fan, \& Dwyer, 2019). Empirical evidence shows that technology has a positive significant effect on the SME performance in South Sulawesi (Munizu, 2010).

Despites financial literacy and financial technology, financial behavior is also considered as an important for determining business success. Financial behavior is someone's ability in organizing daily finance such as planning, budgeting, auditing, managing, controlling, seeking, and saving (Kholilah \& Iramani, 2013). The MSME which focuses on increasing profit usually has a strong will to seek for additional source of fund as the result of their accountable financial behavior (Xiang \& Worthington, 2015). Therefore, financial behavior is one of the important factors in determining the success of a business.

Empirical studies confirm that financial behavior determines the success of the business. For example, Humaira and Sagoro (2018) asert that financial behavior had a significant effect on MSME performance. Rasheed and Siddiqui (2019) report that the MSME owner awareness on finance product and procedure significantly influenced their attitude in making financial decision.

However, previous studies show that many factors are related to the failure of MSMEs. For example, Fatoki (2014) reports that the failure rate for new
MSMEs is very high in Africa, and one of the causes is the failure of financial organizations to survive and grow. Financial literacy is important in order to help finance and make decisions (business and personal).

Based on the background above, this research aims to analyze the quality of financial literacy of the owner-managers of MSMEs in Probolinggo City, East Java Province of Indonesia. In particular, it explores the financial behavior and technology used by the MSMEs. The exploration of financial behaviors among the owners of MSMEs is the focus of the study as previous studies mostly are directed on the examination on the factors that influence financial literacy (Hussain et al., 2018) or examination of financial literacy as the main factor to affect the company's financial performance (Hossain, 2020; Li \& Qian, 2020). So, by focusing on the description of the financial literacy, some new insights can be generated that could exposs the financial behavior of among the owners of MSMEs in Probolinggo City, East java Province.

The City of Probolinggo is selected as the object of the study given the program of the local government to open 500 new business units every year. The research results are expected to be a consideration for the local government in Probolinggo City.

\section{Research Method}

This type of research is a descriptive-based quantitative study. The data were collected through questionnaires to determine the financial literacy level, technology utilization and financial behavior of the consumption sector MSME's owners in Probolinggo City. The secondary data were obtained from the office of cooperative, micro business, trade, and industry of Probolinggo City and other sources. It uses the descriptive analysis to describe the respondent's characteristics.

The population of this study are MSMEs, covering three subsectors, namely culinary, fashion and handcraft. The selected MSMEs must meet certain criteria. It must have been in operation for a minimum of three years. It must utilize information technology in running the business. The sampling process is shown in Table 1 .

The final samples consist of 51 MSMEs. There are 25 MSMEs in the culinary subsectors, 17 in the fashion subsector, and nine in the handycraft subsector. The owners-managers were given a questionnaire that consists of various aspects including the demography issues and the description of the variables. 
Table 1

Sample Selection Process

\begin{tabular}{lc}
\hline \multicolumn{1}{c}{ Criteria } & $\begin{array}{l}\text { Number } \\
\text { MSMEs }\end{array}$ \\
\hline $\begin{array}{l}\text { Number of MSMEs registered with the } \\
\text { Probolinggo City DKUPP until 2018 }\end{array}$ & 5033 \\
$\begin{array}{l}\text { MSMEs are not included in the culinary, } \\
\text { fashion and handiscraf subsectors }\end{array}$ & $(4768)$ \\
$\begin{array}{l}\text { MSME included in culinary, fashion and } \\
\text { handiscarf subsectors }\end{array}$ & 265 \\
$\begin{array}{l}\text { MSMEs that have been operating for less than } 3 \\
\text { years }\end{array}$ & $(214)$ \\
Total sample according to the creteria & 51 \\
\hline
\end{tabular}

\section{Measurement of the Variables}

There is no standard measurement of the level of financial literacy (Cole \& Fernando, 2008). According to the Banking Association of South Africa, the measures of financial literacy for entrepreneurs should include an understanding of financial questionnaires and personnel, accounting and financial management systems, financial products and financial risks, investment capital and legal and tax issues. Fatoki (2014) uses the following conceps to measure the financial literacy of new micro entrepreuners, namely financial planing, analysis and control, book keeping, understanding of funding sources, business terminology, finance and information skills, use to technology, and risk management (insurance). customers (Psomas \& Jaca, 2016).

\section{Financial Literacy Variable}

Following Fatoki (2014), the study explores five indicators to measure the financial literacy of the MSME owner. These are (1) Financial planning, budgeting and control (2) Book-keeping (3) Source of funding (4) respondent's business understanding (5) risk management. The indicators (1) and (2) were expressed in the form of questionnaire which had 1-3 Likert scale where 1 means never, 2 means rarely, and 3 means always. Meanwhile, indicators (3), (4), and (5) were measured using nominal scale of Yes and No option of answer.

\section{Technology Utilization Variable}

This study provides several questions to measure the technology utilization in the MSME activities related to the technology utilization in the business activity; technology utilization in providing easier payment for shopping, bills, and product purchase for the customer; technology utilization in the investment activity; technology utilization for online funding/loan; technology utilization for product marketing expansion and maintaining relationship with the customer. This variable is measured using Likert measurement scale 1-3 where 1 means never, 2 means rarely, and 3 means always. Indicators (3), (4), and (5) were measured by using "Yes and No" nominal scale.

\section{Financial Behavior Variable}

This study determines the MSMEs' owner financial behavior through several statements including punctuality in paying the bills, the habit of making financial budget, recording expenses and other behavior. This variable is expressed using Likert measurement scale 1-3 where 1 means never, 2 means rarely, and 3 means always. For indicators (3), (4), and (5), the study offers a categorical scale, a "Yes and No" answer.

\section{MSME Performance Variable}

The MSME performance is determines using the business profit increase indicator. The data were in the form of profits in the months of August, September, October, and November 2019.

\section{The Analysis Test}

The research analysis begins with a validity test. The reliability test functions to determine whether the questionnaire used in the study can provide the same results if the measurement is repeated, at least for the same respondents. It also uses correlation test to analyze the relationship between variables. The product moment correlation test is carried out to see the relationship between financial literacy variables at points of financial planning, budgeting and control as well as accounting variables on performance. Other variables to be tested are financial behavior and the use of technology on performance. Biserial Point Correlation is performed when the data were in the form of nominal scales. These include the source of funding, business understanding by the respondent, risk management, and the MSME performance.

\section{Results and Discussion}

From the total 51 respondents, 41 MSME owners are female and the rest are male. There were 48 units considered as micro scale business since it has less than 10 employees. Two MSMEs were considered as small scale business since it has around 10 to 30 employees. One MSME is considered as medium scale business 
since it has more than 30 employees. There are 35 MSMEs have been in operation for 3-5 years, 13 MSMEs have been existing for 5-10 years, and three MSMEs have been running the business more than 10 years.

\section{The Financial Literacy Level}

Table 2 shows the data on the financial literacy indicators. As shown in the table, the average financial literacy of the owners-managers of MSMEs is $68.8 \%$. It is considered as fair (Rasheed \& Siddiqui, 2019). This figure suggests that the respondents have not yet mastered the knowledge and skills related to the financial product and service. The lack of knowledge causes difficulty for the respondents to access the financial product and to make the proper and optimum financial decision.

Table 2

Indicator of Financial Literacy

\begin{tabular}{lc}
\hline \multicolumn{1}{c}{ Indicator } & \% \\
\hline Financial Planning, budgeting, and control & 72.2 \\
Bookkeeping & 62.8 \\
Source of Funding & 61.9 \\
Business Understanding of the Respondents & 51.5 \\
Risk Management & 95.7 \\
Average & 68.8 \\
\hline
\end{tabular}

Table 3 presents the results of financial planning, bidgeting and control of the respondents. The results indicate that the majority of the MSME owners have made financial planning, budgeting, and control very well, started from initial financial planning of the business, knowing the detail of the business needs, comparing the revenue and cost, and operating business as they had planned. However, most of the MSME owners could not always match the realization target with their financial planning. The owner could make the financial planning, budgeting, and control, but the implementation is different due to their lack of financial knowledge.

Table 3

Financial Planning, Budgeting, and Control

\begin{tabular}{lccc}
\hline \multicolumn{1}{c}{ Statement } & N & R & A \\
\hline $\begin{array}{l}\text { Do you financial planning at the } \\
\text { beginning of the business? }\end{array}$ & 3.9 & 35.3 & 60.8 \\
$\begin{array}{l}\text { Do you organize the financial } \\
\text { planning to be on target? }\end{array}$ & 3.9 & 66.7 & 29.4 \\
$\begin{array}{l}\text { Do you know the detail of any needs } \\
\text { in my business? }\end{array}$ & - & 5.9 & 94.1 \\
$\begin{array}{l}\text { Do you compare the cost I spent to } \\
\text { the profit I get? }\end{array}$ & - & 5.9 & 94.1 \\
$\begin{array}{l}\text { Do you consider my business } \\
\text { matches my initial planning? }\end{array}$ & - & 17.6 & 82.4 \\
\hline $\begin{array}{l}\text { Note: } \mathrm{N}=\text { never, } \mathrm{R}=\text { rarely, A= always } \\
\text { noly }\end{array}$ & & &
\end{tabular}

Table 4 provides the results of book-keeping literacy of the respondents. It can be seen that most of the MSME owners any incomes and expenses even if the amount is considered as small. Bookkeeping is a part of financial report aimed to find out the operating cost, debt, and calculate the tax payment.

Table 4

Bookkeeping

\begin{tabular}{lccc}
\hline \multicolumn{1}{c}{ Statement } & N & R & A \\
\hline Do you keep record the income? & 1.9 & 33.3 & 64.7 \\
$\begin{array}{l}\text { Do you keep record the expenses? } \\
\begin{array}{l}\text { Do you keep a detail record even for } \\
\text { the small income or expenses? }\end{array}\end{array}$ & 2.9 & 31.4 & 64.7 \\
\hline
\end{tabular}

Note: $\mathrm{N}=$ never, $\mathrm{R}=$ rarely, $\mathrm{A}=$ always

Table 5 summarizes the results of the respondents' knowledge on source of fundings. The data show that most of the MSME owners have a business saving account, make a calculation before taking loan, and the most preferred external sources of funding were from the family/friend and the public bank. The MSME owner did not prefer the loan from rural banks since the interest rate is higher than the public bank. Most of the owners did not know government program of funding which can be accessed by the MSME owners.

\section{Table 5}

\section{Source of Funding}

\begin{tabular}{|c|c|c|}
\hline Statement & Yes & No \\
\hline Do you have a personal bank account. & 84.3 & 15.7 \\
\hline Do you bank your takings on daily & 96.1 & 3.9 \\
\hline $\begin{array}{l}\text { Where you can get finance from } \\
\text { family or close friends? }\end{array}$ & 25.5 & 74.5 \\
\hline $\begin{array}{l}\text { Where you can get finance from the } \\
\text { public bank loan (BNI, BCA, BRI, } \\
\text { etc)? }\end{array}$ & 39.2 & 60.8 \\
\hline $\begin{array}{l}\text { Where you can get finance from the } \\
\text { BPR loan (rural bank)? }\end{array}$ & 7.8 & 92.2 \\
\hline $\begin{array}{l}\text { Where you can get finance from the } \\
\text { daily loan? }\end{array}$ & & 100 \\
\hline $\begin{array}{l}\text { Where you can get finance from capital } \\
\text { assistance provider organization such } \\
\text { as PNM (Permodalan Nasional } \\
\text { Madani)? }\end{array}$ & 13.7 & 86.3 \\
\hline
\end{tabular}

Table 6 shows the results related to business knowledge. It shows that that most of the MSME owners have the basic knowledge on business and financial terms such as savings, loan, insurance, and installment. Meanwhile, there were some business knowledge they did not yet understand. Their lack of knowledge makes them difficult to access the information related to the financial service and product they can use to improve the MSME performance. 
Table 6

Business Knowledge

\begin{tabular}{lcc}
\hline \multicolumn{1}{r}{ Statement } & Yes & No \\
\hline Savings & 100 & 0 \\
Loan & 86.2 & 13.7 \\
Investment & 66.7 & 13.3 \\
Insurance & 62.7 & 37.3 \\
Credit Card & 52.9 & 47.1 \\
Installment Payment & 68.6 & 31.4 \\
Stock Market & 19.6 & 80.4 \\
Business Plan & 43.1 & 56.9 \\
Tax Percentage & 35.3 & 64.7 \\
Inflation Rate & 13.7 & 86.3 \\
Exchange Rate & 15.7 & 84.3 \\
Interest Rate & 17.6 & 82.4 \\
\hline
\end{tabular}

Table 7 shows the results of risk management of the respondents. It can be seen that most of the MSMEs owner have the knowledge concerning risk management, and understand the material risk, selling risk, other risks, and they have the solution for those risks.

Table 7

Risk Management

\begin{tabular}{lcc}
\hline \multicolumn{1}{c}{ Statement } & Yes & No \\
\hline $\begin{array}{l}\text { Do you understand business insurance? } \\
\begin{array}{l}\text { Do you understand the risk of } \\
\text { inventory? }\end{array}\end{array}$ & 94.1 & 5.9 \\
$\begin{array}{l}\text { Do you understand the risk of } \\
\text { credit selling? }\end{array}$ & 98.0 & 2.0 \\
$\begin{array}{l}\text { Do you understand other risks } \\
\text { which threaten the business? }\end{array}$ & 94.1 & 5.9 \\
$\begin{array}{l}\text { Do you have a solution to overcome the } \\
\text { risk with business insurance? }\end{array}$ & 5.9 & 94.1 \\
\hline
\end{tabular}

Table 8 depicts the results of technology utilization of the respondents. It can be seen that MSME owners have not yet maximize the technology utilization. The owners utilize the technology to expand the product marketing and to maintain the relationship with customers; they have not yet utilized technology for investment and funding. The less maximum technology utilization will cause difficulty for the MSME to compete others which have been utilizing the technology.

Table 9 presents the results of the respondents' financial behavior. It sows that most of MSME owners have shown accountable financial behaviors such as paying the bill punctually, comparing price before making a purchase, considering some alternatives in making financial decision and adjusting the financial condition to fulfill the emergency financial situation. The MSME owner with an accountable financial behavior will be able to consider and plan their financial resource to be managed properly to improve the MSME performance.
Table 8

Technology Utilization

\begin{tabular}{|c|c|c|c|}
\hline $\begin{array}{c}\text { Statement } \\
\end{array}$ & $\mathbf{N}$ & $\mathbf{R}$ & $\mathbf{A}$ \\
\hline \multicolumn{4}{|l|}{$\begin{array}{l}\text { Have you been utilizing technology } \\
\text { to ease the business activity (such }\end{array}$} \\
\hline $\begin{array}{l}\text { as utilizing machine in the } \\
\text { manufacturing process, etc)? }\end{array}$ & 29.4 & 25.5 & 45.1 \\
\hline \multicolumn{4}{|c|}{ Have you been utilizing technology } \\
\hline $\begin{array}{l}\text { for shopping payment, bills, or } \\
\text { product purchase by the customer } \\
\text { (such as bank transfer, OVO, } \\
\text { Gopay)? }\end{array}$ & 13.7 & 35.3 & 51 \\
\hline $\begin{array}{l}\text { Have you been utilizing technology } \\
\text { for the investment activity (Such } \\
\text { as Bareksa and IpotFund)? }\end{array}$ & 92.2 & 5.9 & 2.0 \\
\hline $\begin{array}{l}\text { Have you been utilizing technology } \\
\text { for funding (such as online loan)? }\end{array}$ & 84.3 & 15.7 & 0 \\
\hline $\begin{array}{l}\text { Have you been utilizing technology } \\
\text { to ease the product marketing } \\
\text { expansion such as social media, } \\
\text { BukaLapak, Shopee, or other } \\
\text { platform? }\end{array}$ & 19.6 & 17.6 & 62.8 \\
\hline $\begin{array}{l}\text { Have you been utilizing technology } \\
\text { to maintain the relationship with } \\
\text { the customer (such as through } \\
\text { WhatsApp or e-mail)? }\end{array}$ & 3.9 & 5.9 & 90.2 \\
\hline Mean & 48.7 & 15.4 & 35.9 \\
\hline \multicolumn{4}{|c|}{ Note: $\mathrm{N}=$ never, $\mathrm{R}=$ rarely, $\mathrm{A}=$ always } \\
\hline \multicolumn{4}{|l|}{ Table 9} \\
\hline Frequency Financial Behavior & & & \\
\hline
\end{tabular}

Do you pay the bills punctually (employee wages, electricity bill, etc.)?

$9.8 \quad 90.2$

Do you make a financial budget periodically (daily, monthly, etc.)? $\quad$ - $\quad 64.7 \quad 35.3$

Do you record the payment and expenses (daily, monthly, etc.)?

$\begin{array}{llll}\text { Do you save my money regularly? } & 2.0 & 49.0 & 49.0\end{array}$

Do you compare the price before making purchase decision?

$\begin{array}{lll}2.0 & 7.8 \quad 90.2\end{array}$

$\begin{array}{llll}\text { Do you determine financial target? } & 2.0 & 66.7 & 31.4\end{array}$

Do you have predicted the income accurately?

$2.0 \quad 43.1 \quad 56.4$

Do you have predicted the cost accurately?

I consider several alternatives in making financial decision?

$\begin{array}{lll}- & 11.8 \quad 88.2\end{array}$

I adjust my financial condition to fulfill the emergency financial situation.

$\begin{array}{ll}- & 15.7 \quad 84.3\end{array}$

Mean

$\begin{array}{lll}1.4 & 36.6 \quad 62.0\end{array}$

Note: $\mathrm{N}=$ never, $\mathrm{R}=$ rarely, $\mathrm{A}=$ always

The results obtained in Table 9 indicate that most of the owners have shown accountable financial 
behaviors such as paying the bill punctually, comparing price before making a purchase, considering some alternatives in making financial decision and adjusting the financial condition to fulfill the emergency financial situation. The owners with an accountable financial behavior will be able to consider and plan their financial resource to be managed properly to improve the MSME's performance.

The performance of MSMEs is measured in four consecutive months, August, September, October, and November 2019. The summary is shown in Table 10. As shown in Table 10, it is found that there are $48 \%$ of culinary MSMEs, 53\% of fasion and 56 handicrafts in good categories which are marked with profit growth while the rest are still in poor condition.

Table 10

MSME Performance Indicators

\begin{tabular}{lcccc}
\hline \multirow{2}{*}{ Subsector } & \multicolumn{4}{c}{ MSME's Performance } \\
\cline { 2 - 5 } & Good & \% & Not Good & \% \\
\hline Culinary & 12 & 48.0 & 13 & 52.0 \\
Fashion & 9 & 52.9 & 8 & 47.1 \\
Handycraf & 5 & 55.6 & 4 & 44.4 \\
\hline
\end{tabular}

To further analyze the interrelation between vaiables, the product moment correlation test is performed. Product moment correlation is used to analyze interval or ratio scale data with interval or ratio scale data. The test is intended to analyze the relationship between financial literacy variables for financial planning, budgeting and control as well as accounting variables on performance, and financial behavior variables and the use of technology on performance. Table 11 presents the summary of correlation tests.

Table 11

Results of Correlation Tests

\begin{tabular}{llcc}
\hline \multicolumn{1}{c}{ Variable } & \multicolumn{1}{c}{ Incicator } & CC & Sig. \\
\hline Financial & $\begin{array}{l}\text { Financial } \\
\text { Planning, }\end{array}$ & -0.03 & 0.82 \\
& $\begin{array}{l}\text { Budgeting, and } \\
\text { Control } \\
\text { Bookkeeping }\end{array}$ & -0.16 & 0.27 \\
Technology & & -0.09 & 0.50 \\
Utilization & & 0.09 & 0.49 \\
$\begin{array}{l}\text { Financial } \\
\text { Behavior }\end{array}$ & & & \\
\hline
\end{tabular}

As shown in Table 11, the correlation between financial literacy, use of technology and financial behavior is very small so it can be said to be uncorrelated. This shows that the planning and use activities as well as the behavior of MSMEs have not fully led to creating increased profits. From the MSME data, there are those who have always planned their finances by $72.2 \%$, and recorded $62.8 \%$ of finances, but the use of technology is not always because those who use it are quite low, 35.9\%, others are still far from technology. The financial behavior of MSMEs is $62 \%$ stated that their activities have led to financial management, although there are $38 \%$ who do not always even try to be modest.

Further test is performed using biserial point correlation on three variables, including source of funding, business knowledge, and risk management. Biserial Point Correlation is used to analyze interval or ratio scale data with dichotomous data. Table 12 summarizes the results.

Table 12

Correlation Source of Funding, Business Knowledge, and Risk Management

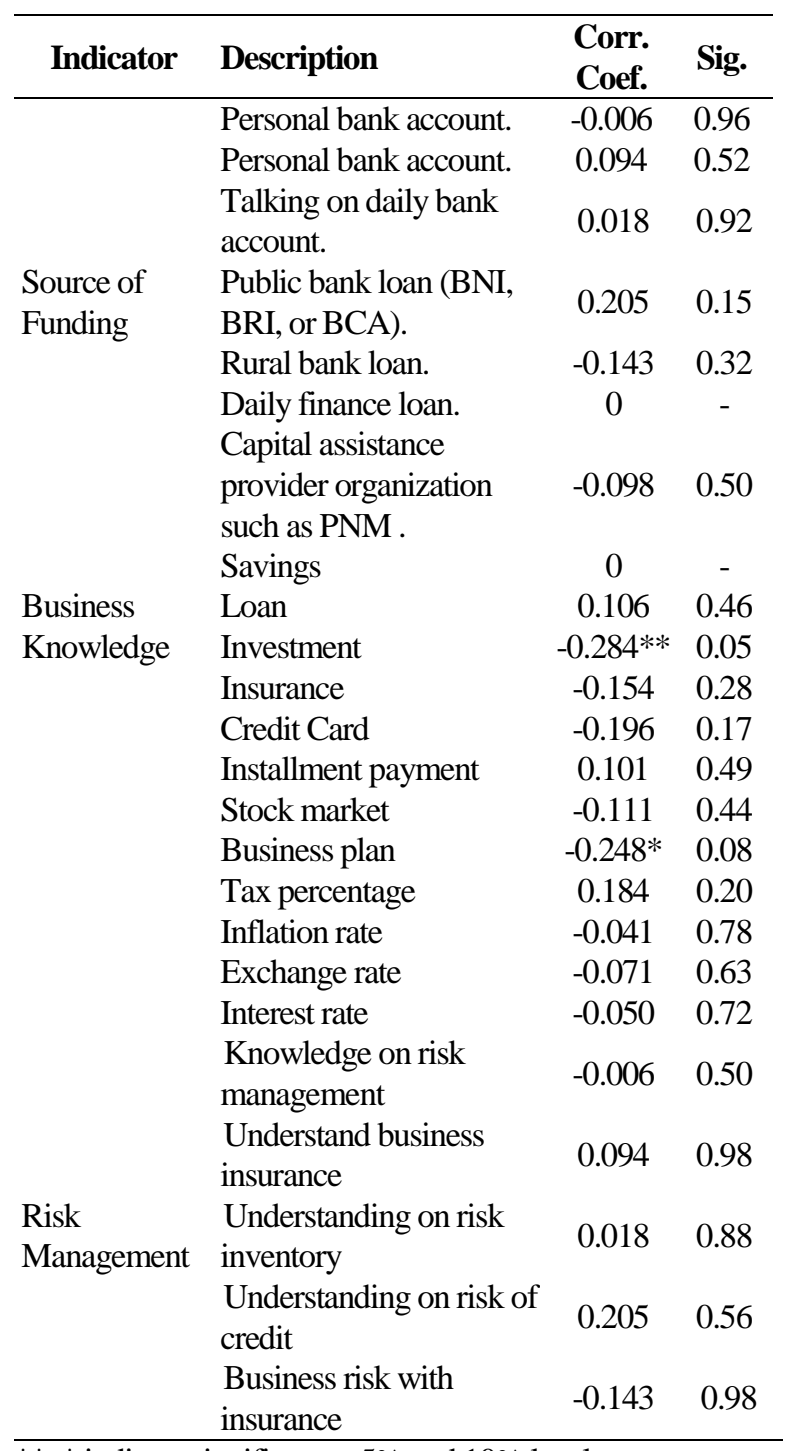

**, * indicate significant at 5\% and $10 \%$ levels, respectively. 
In Table 12, it can be seen that there is no relationship between indicators of funding sources, risk management and MSME performance, however in business understanding there is a negative relationship between investment indicators and business plans. This result indicates that MSMEs on investment are getting lower, this explains that MSMEs actually know about other investments, but because the performance of MSMEs is low, they cannot do much, apart from pursuing their business. This is supported by knowing their understanding of the business, but not the least they do not understand. On the business plan point also indicates that the more MSMEs know the plans, the lower the performance, because businesses at MSMEs need focus because there are indeed many obstacles to have, to have a good performance.

The findings reported in this study partly support the evidence reported by Hossain (2020) that there is a relationship between financial literacy and business performance. Although not all indicators of financial literacy are strongly related to other indicators, the results reported in this study may portrait the fact that financial literacy is important and could be related to record keeping, performance or risk management. In the same spirit of this issue is Mabula and Ping (2018) who document that firm use of technology, record keeping, performance, and risk management are associated with financial literacy.

In addition, given that the study find a positive and significant correlation between business plan and business knowledge, we might argue that the owners of MSMEs to certain extent have include business plan in their daily activity. Business plan is considered to be important as it could provide a benchmark of performance that could be used as the basis for analysising the potential of the business (future growth). Hussain $e t$ al. (2018) examine the SMEs in England and report that financial literacy could have a positive impact on future growth.

\section{Conclusion}

The financial literacy of MSME's owners in Probolinggo city is considered as fair with $68.8 \%$. The result indicated that the MSME owners in Probolinggo City have not yet mastered the knowledge and skills concerning financial product and service. Also, they have not yet utilized the technology maximally to assist the business activity that impacted on the less maximum performance of the MSME in Probolinggo City. However, the owners have shown an accountable financial behavior that they are able to manage their financial resource well and improve the MSME performance.
Given the study can be said as the preliminary study, future study may explore the issues on the relationship between financial literacy and entrepreneurial participation or entrepreneurial performance as studied by Li and Qian (2020). In addition, future study may explore further the factors that determine the extent of financial literacy among owners of MSMEs in other cities or districts.

\section{References}

Abor, J., \& Quartey, P. (2010). Issues in SME development in Ghana and South Africa. Journal of Finance and Economics, 39(6), 219-227.

Ardiansari, A., Cahyaningdyah, D., \& Slamet, A. (2016). Electronic financial behavior profile for improving SMEs financial literacy in Semarang. International Journal of the Computer, the Internet and Management, 24(3), 117-120.

Aribawa, D. (2016). Pengaruh literasi keuangan terhadap kinerja dan keberlangsungan UMKM di Jawa Tengah. Jurnal Siasat Bisnis, 20(1), 1-13.

Cole, S., \& Fernando, N. (2008). Assessing the importance of financial literacy. ADB Finance for the Poor, 9(2), 1-6

Fatoki, O. (2014). The financial literacy of micro entrepreneurs in South Africa. Journal of Social Sciences, 40(2), 151-158.

Humaira, I., \& Sagoro, M.E. (2018). Pengaruh pengetahuan keuangan, sikap keuangan dan kepribadian terhadap perilaku manajemen keuangan pada pelaku UMKM Sentra Kerajinan Batik Kabupaten Bantul. Jurnal Nominal, 7 (1), 96110.

Hussain, J., Salia, S., \& Karim, A. (2018). Is knowledge that powerful? Financial literacy and access to finance: An analysis of enterprises in the UK. Journal of Small Business and Enterprise Development, 25(6), 985-1003.

Hossain, Md. M. (2020). Financial resources, financial literacy and small firm growth: Does private organizations support matter? Journal of Small Business Strategy, 30(2), 35-58.

Kasendah, B. S., \& Wijayangka, C. (2019). Pengaruh literasi keuangan terhadap kinerja UMKM. Jurnal Manajemen dan Bisnis, 3(1), 153-160.

Kemenperin (2016). Kontribusi UMKM naik. Retrieved from: Https: //kemenperin.go.id/artikel/1420 0/Kontribusi-UMKM-Naik.

Kholilah, N.A., \& Iramani, R. (2013). Studi financial management behavior pada masyarakat Surabaya. Journal of Business and Banking, 3(1), 6980. 
Krishna, A., Rofaida, R., \& Sari, M. (2010). Analisis tingkat literasi keuangan di kalangan mahasiswa dan faktor-faktor yang mempengaruhinya. Proceedings of the 4th International Conference on Teacher Education, Bandung, Indonesia.

Li, R., \& Qian, Y. (2020). Entrepreneurial participation and performance: The role of financial literacy. Management Decision, 58(3), 583-599.

Lusardi, A., Mitchell, O. S., \& Curto, V. (2010). Financial literacy among the young. Journal of Consumer Affairs, 44(2), 358-380.

Mabula, J. B., \& Ping, H. D. (2018). Use of technology and financial literacy on SMEs practices and performance in developing economies. International Journal Advanced Computer Science and Applications, 9(6), 74-82.

Munizu, M. (2010). Pengaruh faktor eksternal dan internal terhadap kinerja usaha mikro dan kecil di Sulawesi Selatan. Jurnal Manajemen dan Kewirausahaan, 12(1), 33-41.

Niebel, T. (2018). ICT and economic growth: Comparing developing, emerging and developed countries. World Development, 104 (C), 197 211.
Okundaye, K., Fan, S. K., \& Dwyer, R. J. (2019). Impact of information and communication technology in Nigerian small to medium sized enterprises. Journal of Ecomomics, Finance, and Administrative Science, 24(47), 29-46.

Psomas, E. L, \& Jaca, C. (2016). The impact of total quality management on service company performance: Evidence from Spain. International Journal of Quality \& Reliability Management, 33(3), 380-398.

Rasheed, R., \& Siddiqui, S. (2019). Attitude for inclusive finance: Influence of owner-managers' and firms' characteristics on SMEs financial decision making. Journal of Economic and Administrative Science, 35(3), 158-171.

Xiang, D., \& Worthington, A. (2015). Finance-seeking behahiour and outcomes for small-and mediumsized enterprises. International Journal of Managerial Finance, 11(4), 513-530.

Yunis, M., El-Kassar, A., \& Tarhini, A. (2017). Impact of ICT-based innovations on organizational performance: The role of corporate entrepreneurship. International Journal of Enterprise Information Management, 30(1), 122-141. 